\title{
Nuclear, Renewables and Low Carbon Growth: A Comparative Study on China, U.S., France and Japan
}

\author{
Xiaoling Wang ${ }^{1}$, Jingtao Yu ${ }^{2 *}$, Minmin Zhang², Xi Qin² \\ ${ }^{1}$ School of Economics and Management, University of Science and Technology Beijing, Beijing, China \\ ${ }^{2}$ School of Economics and Management, Dalian University of Technology, Dalian, China
}

Received: 26 March 2018

Accepted: 7 August 2018

\begin{abstract}
Using the ARDL test and Granger approaches, this paper investigates long-term co-integration and causal relationships among nuclear, renewables, GDP and $\mathrm{CO}_{2}$ emissions in China, US, France and Japan. The findings reveal that the long-term coefficient of nuclear energy is smaller than renewable energy, indicating a relative advantage of nuclear power. However, the emission reduction effect of nuclear and renewables in China was not as much as compared to other nations. Moreover, causality from economic growth to nuclear or renewable energy existed in all countries, whereas no causality from nuclear energy to economic growth existed except in Japan. Therefore, giving priority to energy conservation and energy mix optimization is not likely to hurdle economic growth in China. However, greenness of the overall energy production process, augmentation of energy efficiency, technological progress in energy storage and internet, sustainable development of resource-society, and nuclear safety issues should be given priority in order to contribute to low-carbon growth in China.
\end{abstract}

Keywords: nuclear; renewables; low-carbon growth; ARDL-VECM

\section{Introduction}

Climate change, mainly introduced by extensive carbon dioxide emissions, is at the forefront of today's environmental concerns, and each country and region is responsible for making contributions to address such issues as indicated at the Copenhagen Climate Conference [1, 2]. The Paris Agreement that was released on 12 December 2015, as part of the United Nations

*e-mail:jyudl@dlut.edu.cn
Framework Convention on Climate Change (UNFCCC), is considered a milestone of global governance in dealing with greenhouse gas emissions mitigation, adaptation, and finance. The Chinese government has set strict abatement targets to decrease its carbon emission intensity by $60-65 \%$ (from 2005 levels) by 2030 and meet its emission peak around the same time [3]. Although the United States has withdrawn from the agreement (in early 2017), as the biggest emitter worldwide, China is determined to undertake its own responsibilities in controlling climate variation [4]. As such, enormous changes in balancing economic growth 
and emissions abatement under the "new normal" situation are facing the Chinese government [5].

Energy, in various formats, has played an important role in human civilization. With its significant economic, environmental, and strategic attributes, decarbonization of energy systems is crucial in realizing low-carbon development in economies. Therefore, decoupling fossil energy consumption from economic growth by implementing large-scale renewables projects including hydro, wind, solar, and nuclear power is recognized as the key to low-carbon and green growth [6]. Large-scale utilization and promotion of clean energy started to become popular in the 1970s with the pressures that came from traditional energy shortages and global warming. The development of renewables and nuclear power was rapid in the mid-1990s, when industrialization was available, due to market demand and maturing technologies. According to World Bank statistics, the share of renewables and nuclear power in global total electricity generation was already more than one quarter in 2013 [7].

Coal has accounted for $70 \%$ of the energy mix in China for a long time, thus transitioning to a low-carbon energy system with the help of structural change is a pressing issue for the country. The Chinese government has been aggressively investing in clean energy projects in order to release the benefits of energy transition in both economic growth and emissions reduction [8]. China currently has the most nuclear power stations under construction worldwide, and accounts for 36\% of global investment on renewables (excluding hydro projects over $50 \mathrm{MW}$ ) in the amount of $\$ 102.9$ billion US [9].

In view of the significant impacts created by Chinese economic expansion on energy consumption and environmental quality, quantitative analyses on causal relationships among nuclear, renewables, and economic growth are essential for policy-making on energy and environmental issues. To the best of our knowledge, studies on the relationships between the development of alternative energy sources and economic growth from the perspective of international comparison are relatively rare. Accordingly, this paper attempts to answer the following questions: "whether the development of nuclear and renewables will help in carbon emissions curtailment," "how the effects of nuclear power on emission reduction compares to the effects of renewables," and "whether there are causal relationships between the expansion of nuclear, renewables and economic growth."

\section{Literature Review}

Research on the relationship between environmental pollution, energy consumption, and economic growth has been a part of the energy economics literature for the past two decades [10]. One study, from Kraft and Kraft [11] in the 1970s, has had a profound impact on the research regarding the relationship between economic growth and energy consumption. Since the study was published, numerous empirical studies have been conducted to discuss the causality among economic development, electricity generation, and energy consumption. However, the direction of causality between energy or electricity consumption and economic variables has remained empirically elusive and controversial.

So far, four dominating hypotheses have been found: the growth hypothesis as a unidirectional causality running from energy consumption to economic growth exists (i.e., economic growth is dependent on energy consumption); the conservation hypothesis as a unidirectional causality running from economic growth to energy consumption exists (i.e., energy consumption is a result of economic growth); the feedback hypothesis as a bidirectional causality exists between energy consumption and economic growth (i.e., energy consumption and economic growth interact as both cause and effect); and the neutrality hypothesis when absence of causality in any direction appears.

Causal relationships exert large impacts on energy-related policy decisions. Suppressing energy consumption may lead to an economic recession when the growth hypothesis is supported, and any energy policy encouraging conservation might adversely affect economic growth. This phenomenon is confirmed by studies from AL-Iriani [12], Mehrara [13], and Alam et al. [14]. On the contrary, implementing energy-saving policies is not likely to hinder economic prosperity when the conservation hypothesis stands $[15,16]$. Recent studies by Stern [17], Oh and Lee [18], Yuan et al. [19], Narayan and Smyth [20], and Apergis and Payne [21] have favored this statement. In the third case, a feedback relationship between energy consumption and economic growth reveals the energy-dependent feature of an economy; thus the reduction of energy consumption will be at the cost of economic prosperity while economic expansion policy would stimulate energy consumption. This hypothesis is supported by empirical research, including Masih and Masih, Paul and Bhattacharya, and Lee et al. [22-24]. The neutral hypothesis, acknowledged by Cheng and Jobert and Karanfil [25, 26], gives flexibility to policy-making decisions as no causal relation exists between the two variables. Based on a summary of the literature regarding the theme, Omri has found that the percentages of the studies supporting the four hypotheses were $31 \%, 28 \%, 23 \%$, and $18 \%$ respectively [27].

Development of alternative energy sources including nuclear and renewables have been identified as a critical and practical way to address climate change, energy security, and economic growth. This argument also inspires the formation of an up-to-date research topic regarding relationships among the variables. However, the results of the relationships between renewable energy consumption and economic growth showed something slightly different, as most empirical research supported 
the conservation hypothesis and the neutral hypothesis $[28,29]$. Only a few studies, including one empirical study based on panel data of 18 emerging countries from Sadorsky [30] and one empirical study based on panel data of nine advanced economies from Rufael and Menyah [31], presented evidence of bidirectional causality between renewable energy consumption and economic growth, supporting the existence of the feedback hypothesis.

In terms of the relationships between nuclear consumption and economic development, neutral hypothesis was found by Bowden and Payne [32] and Rufael [33] in the U.S. and Taiwan, yet the scholars didn't consider the impacts of carbon emission during the utilization processes of nuclear power. Growth hypothesis was supported in the empirical studies on South Korea, India, and France by $\mathrm{Yoo}$ and $\mathrm{Ku}$, Rufael, and Mbarek and Khairallah [34-36]. Little research has been done on the causality between nuclear production and carbon emissions, while the comparative advantage of nuclear to fossil fuels in long-term emission reduction has been confirmed by Iwata et al. and Baek and Kim [37, 38]. However, these studies didn't discuss the impact of other clean energies on climate change.

Existing research has revealed mixed findings regarding the abatement effects of nuclear and renewable energy, leading to divergent views on the true benefits of clean energy development [39]. For example, Lutz Lez questioned the "zero emission" assertion of nuclear power by considering the emissions during the life-cycle of nuclear applications. The study showed that emissions generated from the exploration, mining, processing, disposal, and recycling of uranium should have been considered along with the emissions coming from the production processes of nuclear power stations [40]. Furthermore, studies have revealed that the abatement effects of nuclear energy could be mitigated by its cannibalistic effects [41]. Kenny also pointed out that the energy use during construction of large scale nuclear plants could lead to more accumulative emissions [42]. Therefore, renewable energy is preferred by some scholars as the disadvantages related to nuclear generation, including thermal pollution and risk issues associated with nuclear waste, may exceed the economic and environmental benefits of nuclear utilization [43, 44].

This paper aims to enrich the existing literature in three facets: first, the research focus of this study is "new" energy, including nuclear and renewables (excluding hydro) instead of total energy analysis; second, systematic research is conducted on the relationships among nuclear energy, renewables, carbon emissions, and economic growth to test the existence of the four hypotheses; and finally, a comparative study is conducted by selecting advanced countries worldwide in energy utilization and management as China's peers to cast a light on the implications of China's clean energy policy.

\section{Econometric Model and Data}

\section{Model Construction}

The United States, France, and Japan have been selected as peers of China given their advancement in nuclear power and/or renewable energy. For instance, the U.S. and France are both pioneers in nuclear power utilization, followed by Japan, and they are currently the top three countries in nuclear production worldwide. Furthermore, these countries are also identified as advanced in renewable electricity utilization, including solar, biofuel, and tide power generation. According to reports and statistics from the Renewable Energy Policy Network for the 21st Century and the U.S. Energy Information Agency [45, 46] in 2015, the newly installed capacities of American wind power and biomass power plants was the largest in the world, and the country's total capacity ranked second worldwide following China. France is among the most advanced countries in terms of tidal power generation, and Japan is the biggest solar power generator in Asia. The development experience of these countries will be referenced by the Chinese government when making related polices. This paper thus constructs the model based on the Environmental Kuznets Curve, which can be expressed in the following format:

$$
\left(\mathrm{CO}_{2}\right)_{t}=\alpha_{0}+\alpha_{2} Z_{t}+\alpha_{3} \mathrm{GDP}_{t}+\alpha_{4} G D P^{2}+\mu_{t}
$$

...where $\mathrm{CO}_{2}$ represents quality of environment, GDP represents income level, and $\mathrm{Z}$ represents other factors that influence environmental status. In order to tackle the issue of omitted variables, this paper incorporates primary energy consumption, nuclear power generation, and renewable power generation into formula (1) to get a new model (i.e., formula 2) by referencing the studies of Iwata, Baek and Kim, and Menyah and WoldeRufae.

$$
\begin{aligned}
\ln \mathrm{C}_{t} & =\alpha_{0}+\alpha_{1} \ln N U_{t}+\alpha_{2} \ln R E_{t}+\alpha_{3} \ln E C_{t}+ \\
& +\alpha_{4} \ln G D P_{t}+\alpha_{5} \ln (G D P)^{2}+\mu_{t}
\end{aligned}
$$

...where $C t$ is $\mathrm{CO}_{2}$ emissions per capita in kilo tons, $N U t$ is nuclear power generation per capita in kilo hours, ECt is primary energy consumption per capital in kilo ton of equivalent petroleum, GDPt is real GDP per capita in constant U.S. dollar in 2010, GDPt2 is the square of GDPt per capita, $t$ is time term, and $\mu \mathrm{t}$ is error term.

\section{Econometric Methods}

The vector error correction model (VECM) is used based on the Auto Regressive Distributed Lag (ARDL) bounds and is applied to complete the analyses. 


\section{Co-integration Regression}

Residual tests [47] and maximum likelihood value tests [48] (e.g., the Johansen test) are commonly used in traditional Granger tests. However, these two methods are constrained under conditions like uniformity integrated with variables. Therefore, this paper instead applies the ARDL bounds technique proposed by Pesaran in 2001 [49]. In so doing, endogeneity is out of the question while long-term elastic coefficients can be drawn with or without integration with all variables. Models (3) to (8) are constructed to complete the ARDL tests and are listed in the appendix.

Selection of lag terms in models (3) to (8) is decided by AIC criteria [50]. Narayan boundary values are used for China considering its small sample size [51]. The Lagrange multiplier test, the Newey-West standard error correction, the Breusch-Pagan-Godfrey method, and the Ramsey Reset technique are utilized to test the existence of serial correlation, heteroscedasticity, and specification bias of the models to ensure the robustness of the models and results.

\section{VECM Tests}

The VECM approach is then applied to estimate causalities among the variables. Lag error correction terms (i.e., ECMt-1) and Wald tests are used to identify the long-term and short-term causal relations in formula (9), respectively:

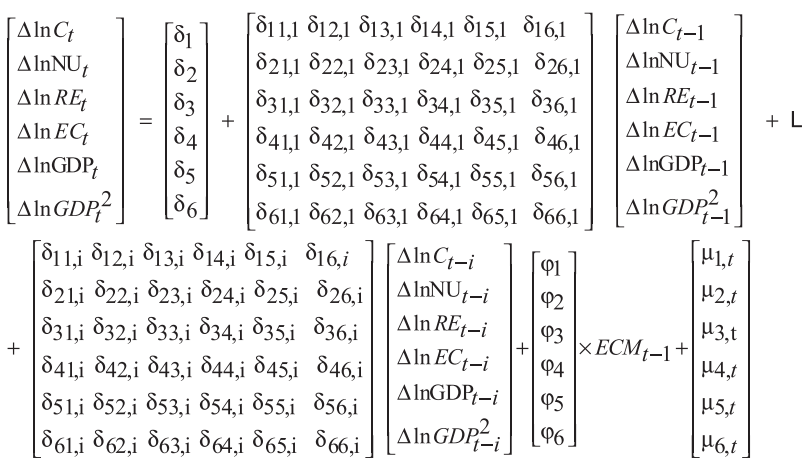

...where ECMt-1 is a first-order delay term of residual, and its coefficient indicates the period for a variable to adjust from a short-run equilibrium to a long-run equilibrium. Error terms are included when long-term relations exist among variables [10].

\section{Results and Analyses}

\section{Statistical Description}

Statistical descriptions of the variables are listed in Table 1, and the data for China are converted into quarterly data due to its short history in developing nuclear power [52].
It can be seen from Table 1, in terms of carbon emissions per capita (C), that the U.S. was the largest emitter worldwide with an average of $19.13 \mathrm{kt}$ per year, and the emissions from France, Japan, and China only accounted for $36.23 \%, 44.01 \%$, and $23.21 \%$ of the American quantity, respectively. In terms of primary energy consumption per capita (EC), the U.S. consumption was about $2.05,2.25$, and 5.48 times that of France, Japan, and China. In terms of renewable power generation per capita (RE), the countries rank from the U.S. at the top, then France, Japan, and China at the bottom. Electricity produced in China was only about $28.20 \%$ of that produced in the U.S. In terms of nuclear power generation per capita (NU), France ranked the highest with an average level of $4105.71 \mathrm{~kW}$ per year, followed by the U.S. and Japan. China's nuclear power production per capita was only about $36.15 \mathrm{~kW}$ per year and was less than 1/10 of the total production of France.

\section{Cointegration Tests}

ARDL tests are conducted after the variables are identified as integrated at least on their first-order differences. The AIC criteria is also utilized to get the lag terms for the model.

According to Table 2, the number of cointegration relationships is four for China, one for the U.S., and two for both France and Japan.

\section{Long-Term Elasticity}

There was no heteroscedasticity nor model misspecification for the models, yet serial correlation did happen for China and France. The Newey-West is then used to revise the models, and long-term elastic coefficients are derived and listed in Table 3.

According to Table 3, all the long-term coefficients for the four countries are positive, whereas the coefficients of GDP2 are all negative, indicating the existence of EKC in all countries.

For China, the long-term elastic coefficients of NU, $\mathrm{RE}$, and $\mathrm{EC}$ to $\mathrm{CO}_{2}$ are significant, with the numbers of $0.01,0.12$, and 0.48 , respectively. A $1 \%$ increase in consumption of nuclear power, renewables, or primary energy will increase carbon emissions by $0.01 \%, 0.12 \%$, and $0.48 \%$, respectively. Although the coefficients of NU and RE are both positive, they are smaller than the coefficient of EC. This outcome supports the comparative advantages of nuclear power and renewable energy generation to fossil fuels in emission reduction. The development of nuclear and renewables could not reduce China's total emissions, but it helped to slow down the growth rate of carbon emissions. The result also acknowledges the positive effects in decarbonizing by increasing the shares of nuclear and renewables in the country's energy mix.

For the U.S. and Japan, only the long-term coefficient of $\mathrm{EC}$ to $\mathrm{CO}_{2}$ is positive, and a $1 \%$ increase in primary energy consumption will introduce emissions growth by 
Table 1. Statistical description of variables.

\begin{tabular}{|c|c|c|c|c|c|c|c|c|c|c|}
\hline & \multicolumn{5}{|c|}{ China (1993-2011) } & \multicolumn{5}{|c|}{ U.S. (1960-2011) } \\
\hline & $\mathrm{C}$ & NU & RE & $\mathrm{EC}$ & GDP & $\mathrm{C}$ & NU & $\mathrm{RE}$ & $\mathrm{EC}$ & GDP \\
\hline Mean & 4.44 & 36.15 & 357.39 & 1354.95 & 2870.92 & 19.13 & 1645.06 & 1263.07 & 7430.69 & 34297.78 \\
\hline SD & 1.91 & 26.82 & 239.96 & 525.25 & 1598.23 & 1.66 & 1091.79 & 215.19 & 671.07 & 10713.50 \\
\hline Min & 2.44 & 1.36 & 128.95 & 788.13 & 994.95 & 15.68 & 3.07 & 816.85 & 5612.08 & 17036.88 \\
\hline \multirow[t]{3}{*}{ Max } & 7.56 & 97.15 & 938.97 & 2236.73 & 6032.62 & 22.51 & 2827.16 & 1745.23 & 8438.40 & 50662.41 \\
\hline & \multicolumn{5}{|c|}{ France (1960-2011) } & \multicolumn{5}{|c|}{ Japan (1966-2011) } \\
\hline & $\mathrm{C}$ & NU & RE & $\mathrm{EC}$ & GDP & $\mathrm{C}$ & NU & $\mathrm{RE}$ & $\mathrm{EC}$ & GDP \\
\hline Mean & 6.93 & 4105.71 & 1125.70 & 3625.56 & 31463.20 & 8.42 & 1280.08 & 796.49 & 3297.82 & 32134.25 \\
\hline SD & 1.38 & 2834.30 & 150.51 & 551.96 & 7697.89 & 1.28 & 940.07 & 93.40 & 675.46 & 9715.58 \\
\hline Min & 4.57 & 31.80 & 824.80 & 2115.42 & 16765.23 & 4.21 & 5.96 & 614.87 & 1477.00 & 13426.23 \\
\hline Max & 9.67 & 7148.42 & 1463.18 & 4301.87 & 41699.17 & 9.91 & 2629.30 & 1062.77 & 4092.71 & 44327.94 \\
\hline
\end{tabular}

$0.99 \%$ and $0.78 \%$ in the U.S. and Japan, respectively. In the meantime, the long-term coefficient of $\mathrm{NU}$ to $\mathrm{CO}_{2}$ are -0.05 and -0.03 , respectively. Although not significant, the positive effects of nuclear power generation on emissions reduction was clearly demonstrated. Although development of renewables had contrary effects in the U.S. and Japan, the effects were not significant in either country.

For France, the elasticity coefficients of GDP, NU, and EC are all significantly positive, and the longterm coefficients of NU, RE, and $\mathrm{EC}$ to $\mathrm{CO}_{2}$ are -0.17 ,
-0.04 , and 0.72 , respectively. The outcome shows that a $1 \%$ increase in consumption of nuclear power and renewables will reduce emissions by $0.17 \%$ and $0.004 \%$, respectively. However, a $1 \%$ increase in primary energy consumption will cause emission growth by $0.72 \%$.

In summary, the impact coefficients on carbon emissions of nuclear power consumption are all negative, which means the development of nuclear energy contributed to the curtailment of emissions during the observation period. The utilization of renewable electricity showed similar effects for the U.S.

Table 2. Co-integration of ARDL bounds.

\begin{tabular}{|c|c|c|c|c|}
\hline \multirow{2}{*}{ Estimation } & \multicolumn{2}{|c|}{ China } & \multicolumn{2}{|c|}{ U.S. } \\
\hline & F value & lag length & F value & lag length \\
\hline$F\left(\ln C \mid \operatorname{lnGDP}, \ln N \mathrm{U}, \operatorname{lnRE}, \operatorname{lnEC}, \operatorname{lnGDP}^{2}\right)$ & 1.57 & $(1,2,2,1,1,1)$ & 0.54 & $(6,6,6,6,6,6)$ \\
\hline$F\left(\operatorname{lnGDP} \mid \ln C, \operatorname{lnNU}, \operatorname{lnRE}, \operatorname{lnEC}, \operatorname{lnGDP}{ }^{2}\right)$ & $5.77 * * *$ & $(1,1,1,1,1,1)$ & 1.16 & $(6,6,6,6,6,6)$ \\
\hline$F\left(\operatorname{lnGDP}{ }^{2} \mid \ln C, \ln N U, \ln R E, \ln E C, \ln G D P\right)$ & $5.74 * * *$ & $(1,1,1,1,1,1)$ & 1.88 & $(5,5,5,5,5,5)$ \\
\hline$F(\operatorname{lnNU} \mid \ln C, \operatorname{lnRE}, \ln E C, \operatorname{lnGDP}, \operatorname{lnGDP} 2)$ & $4.07 * *$ & $(1,1,1,1,1,1)$ & $3.44 *$ & $(6,6,6,6,6,6)$ \\
\hline$F\left(\operatorname{lnRE} \mid \operatorname{lnC}, \operatorname{lnNU}, \operatorname{lnEC}, \operatorname{lnGDP}, \operatorname{lnGDP}^{2}\right)$ & 1.37 & $(1,1,1,1,1,1)$ & 1.40 & $(4,4,4,4,4,4)$ \\
\hline \multirow[t]{3}{*}{$F(\operatorname{lnEC} \mid \operatorname{lnC}, \ln N U, \ln R E, \operatorname{lnGDP}, \operatorname{lnGDP} 2)$} & $3.53 *$ & $(1,1,1,1,1,1)$ & 2.74 & $(5,5,5,5,5,5)$ \\
\hline & \multicolumn{2}{|c|}{ France } & \multicolumn{2}{|c|}{ Japan } \\
\hline & $\mathrm{F}$ value & lag length & F value & lag length \\
\hline$F\left(\ln C \mid \operatorname{lnNU}, \operatorname{lnRE}, \ln E C, \operatorname{lnGDP}, \operatorname{lnGDP}{ }^{2}\right)$ & $5.79 * * *$ & $(2,1,1,1,1,1)$ & 1.97 & $(5,5,5,5,5,5)$ \\
\hline$F\left(\operatorname{lnGDP} \mid \ln C, \operatorname{lnNU}, \operatorname{lnRE}, \ln E C, \operatorname{lnGDP}{ }^{2}\right)$ & 2.71 & $(2,1,1,1,1,1)$ & $3.77^{*}$ & $(5,5,5,5,5,5)$ \\
\hline$F\left(\operatorname{lnGDP}{ }^{2} \mid \ln C, \ln N U, \ln R E, \ln E C, \ln G D P\right)$ & 2.59 & $(1,1,1,1,1,1)$ & $3.78^{*}$ & $(5,5,5,5,5,5)$ \\
\hline$F(\operatorname{lnNU} \mid \ln C, \ln R E, \ln E C, \operatorname{lnGDP}, \operatorname{lnGDP} 2)$ & 2.14 & $(2,1,1,1,1,1)$ & 1.35 & $(6,6,6,6,6,6)$ \\
\hline$F(\ln R E \mid \ln C, \ln N U, \ln E C, \ln G D P, \operatorname{lnGDP} 2)$ & $5.80 * * *$ & $(1,1,1,1,1,1)$ & 2.89 & $(6,6,6,6,6,6)$ \\
\hline$F\left(\operatorname{lnEC} \mid \ln C, \ln N U, \ln R E, \operatorname{lnGDP}, \operatorname{lnGDP}{ }^{2}\right)$ & 1.43 & $(2,1,1,1,1,1)$ & 1.23 & $(5,5,5,5,6,6)$ \\
\hline
\end{tabular}

Note: ${ }^{*} \mathrm{p}<0.1, * * \mathrm{p}<0.05, * * * \mathrm{p}<0.01$ 
Table 3. Long-term elastic coefficient estimations of variables on carbon emissions

\begin{tabular}{|c|c|c|c|c|}
\hline \multirow{2}{*}{ Varable } & \multicolumn{2}{|c|}{ China } & \multicolumn{2}{c|}{ U.S. } \\
\cline { 2 - 5 } & Coefficient & SE & Coefficient & SE \\
\hline lnGDP & 1.50 & 1.65 & 6.03 & 7.62 \\
\hline $\operatorname{lnGDP}{ }^{2}$ & -0.12 & 0.12 & -0.28 & 0.31 \\
\hline $\operatorname{lnNU}$ & $0.01 * *$ & 0.03 & -0.05 & 0.03 \\
\hline $\operatorname{lnRE}$ & 0.12 & 0.21 & -0.01 & 0.03 \\
\hline $\operatorname{lnEC}$ & $0.48 * * *$ & 0.18 & $0.99 * * *$ & 0.28 \\
\hline cons. & -14.14 & 7.12 & -27.96 & 32.53 \\
\hline \multirow{2}{*}{ Variable } & \multicolumn{2}{|c|}{ France } & & Japan \\
\cline { 2 - 5 } & Coefficient & SE & Coefficient & SE \\
\hline $\operatorname{lnGDP}$ & $\mathbf{1 . 2 8} * * *$ & 0.79 & 1.05 & 0.32 \\
\hline $\operatorname{lnGDP}{ }^{2}$ & -0.02 & 0.03 & -0.05 & 0.01 \\
\hline $\operatorname{lnNU}$ & $-0.17 * * *$ & 0.04 & -0.03 & 0.02 \\
\hline $\operatorname{lnRE}$ & 0.04 & 0.18 & 0.29 & 0.25 \\
\hline $\operatorname{lnEC}$ & $\mathbf{0 . 7 2} * * *$ & 0.38 & $\mathbf{0 . 7 8 * * *}$ & 0.24 \\
\hline cons. & $\mathbf{- 1 3 7 . 4 2 * * *}$ & 24.38 & -31.95 & 35.71 \\
\hline
\end{tabular}

Note:* $\mathrm{p}<0.1, * * \mathrm{p}<0.05, * * * \mathrm{p}<0.01$

and France. On the contrary, the emission reduction introduced by the application of nuclear and renewables was not as significant as we expected in China. This phenomenon was also confirmed by another indicator - carbon intensity - which was still high compared to the numbers of France and the U.S. during the same period. This outcome reflects the uncleanliness and non-greenness as well as the "bottle neck" effect in large-scale grid connections and storage during the development of nuclear and renewable industries [53]. Furthermore, the utilization history of nuclear and renewables is relatively short in China compared to the other three countries, thus certain long-term benefits did not appear for China. Nevertheless, the elastic coefficients of NU and RE are both smaller than the coefficient of EC, demonstrating alternative advantages of nuclear and renewables in emission reduction over fossil fuels.

\section{Granger Causality Test}

The VECM model is applied based on the ARDL cointegration analyses in order to observe causal relationships among the variables. The results are listed in Table 4.

As can be seen in Table 4, there were four unidirectional causality relationships in China in the short run: from economic growth to carbon emissions, from economic growth to nuclear power generation, from nuclear production to primary energy consumption, and from economic growth to energy consumption. In the long run, the coefficients of ECM of carbon emissions and nuclear power production are both significantly negative at -0.08 and -0.12 , respectively. This outcome confirms a long-run equilibrium among the variables in China. Moreover, the U.S., France, and Japan also had similar scenarios. The findings support the growth hypothesis for the countries, indicating that conservative energy policy and carbon emissions reduction policy can be advocated without impeding economic growth.

When receiving impulses, the required time of two group variables (i.e., carbon emissions and nuclear power generation) were about 12.5 quarters and 8 quarters, respectively. Although the result implies that economic expansion led to the growth of emissions and the demand in primary energy and nuclear power, economic growth

Table 4. Result of Granger test.

\begin{tabular}{|c|c|c|c|c|c|c|c|c|}
\hline & \multirow{2}{*}{$\begin{array}{c}\text { Dependent } \\
\text { variable }\end{array}$} & \multicolumn{6}{|c|}{ F-statistics } & \multirow{2}{*}{$\frac{\Delta \mathrm{ECM}_{\mathrm{t}-1}}{\text { Statistics }}$} \\
\hline & & $\Delta \ln C_{t}$ & $\Delta \operatorname{lnNU_{t}}$ & $\Delta \operatorname{lnRE_{t}}$ & $\Delta \ln E C_{t}$ & $\Delta \operatorname{lnGDP}{ }_{t}$ & $\Delta \ln \mathrm{GDP}_{\mathrm{t}}^{2}$ & \\
\hline \multirow{12}{*}{ China } & \multirow{2}{*}{$\Delta \ln C_{t}$} & \multirow{2}{*}{ - } & 0.17 & 0.81 & 0.86 & $13.21 * * *$ & $13.77 * * *$ & $-0.08 * * *$ \\
\hline & & & $(-0.67)$ & $(-0.37)$ & $(-0.36)$ & $(0.00)$ & $(0.00)$ & $(-4.27)$ \\
\hline & \multirow{2}{*}{$\Delta \ln N U_{t}$} & 0.01 & \multirow{2}{*}{ - } & 0.01 & 0.15 & $8.43 * * *$ & $8.57 * * *$ & $-0.12 * * *$ \\
\hline & & $(-0.94)$ & & $(-0.94)$ & $(-0.82)$ & $(-0.01)$ & $(-0.30)$ & $(-3.18)$ \\
\hline & \multirow{2}{*}{$\Delta \ln R E_{t}$} & 0.06 & $0.54 \%$ & \multirow{2}{*}{ - } & 0.05 & 0.01 & 0.02 & \multirow{2}{*}{ - } \\
\hline & & $(-0.89)$ & $(-0.90)$ & & $(-0.82$ & $(-0.94)$ & $(-0.86)$ & \\
\hline & \multirow{2}{*}{$\Delta \ln E C_{t}$} & 0.12 & $2.90 *$ & 0.17 & \multirow{2}{*}{ - } & $17.19 * * *$ & $16.80 * * *$ & \multirow{2}{*}{ - } \\
\hline & & $(-0.76)$ & $(-0.09)$ & $(-0.68)$ & & $(0.00)$ & $(0.00)$ & \\
\hline & \multirow{2}{*}{$\Delta \operatorname{lnGDP}{ }_{t}$} & 0.57 & 0.00 & 1.2 & 0.74 & \multirow{2}{*}{ - } & 0.01 & \multirow{2}{*}{ - } \\
\hline & & $(-0.45)$ & $(-0.99)$ & $(-0.28)$ & $(-0.99)$ & & $(-0.93)$ & \\
\hline & \multirow{2}{*}{$\Delta \operatorname{lnGDP}_{\mathrm{t}}^{2}$} & 0.08 & 0.05 & 0.05 & 0.03 & $16.43 * * *$ & \multirow{2}{*}{ - } & \multirow{2}{*}{ - } \\
\hline & & $(-0.78)$ & $(-0.83)$ & $(-0.82)$ & $(-0.87)$ & $(\mathbf{0 . 0 0 )}$ & & \\
\hline
\end{tabular}


Table 4. Continued.

\begin{tabular}{|c|c|c|c|c|c|c|c|c|}
\hline \multirow{12}{*}{ U.S. } & \multirow{2}{*}{$\Delta \ln C_{t}$} & \multirow{2}{*}{-} & 1.6 & 0.29 & 0.95 & 0.38 & 0.38 & \multirow{2}{*}{ - } \\
\hline & & & $(-0.14)$ & $(-0.94)$ & $(-0.56)$ & $(-0.91)$ & $(-0.91)$ & \\
\hline & \multirow{2}{*}{$\Delta \ln N U_{t}$} & 0.87 & \multirow{2}{*}{-} & 0.55 & 0.43 & $1.37 * * *$ & \multirow{2}{*}{$\begin{array}{c}1.34 \\
(0.04)^{* * * *}\end{array}$} & -0.0008 \\
\hline & & $(-0.5)$ & & $(-0.79)$ & $(-0.86)$ & $(-0.03)$ & & $(-2.02)$ \\
\hline & \multirow{2}{*}{$\Delta \operatorname{lnRE} E_{t}$} & 0.97 & $2.02 *$ & \multirow{2}{*}{ - } & 1.38 & 0.75 & \multirow{2}{*}{$\begin{array}{c}0.76 \\
(0.55)\end{array}$} & \multirow{2}{*}{-} \\
\hline & & $(-0.42)$ & $(-0.09)$ & & $(-0.24)$ & $(-0.56)$ & & \\
\hline & \multirow{2}{*}{$\Delta \operatorname{lnEC_{t}}$} & 0.71 & 0.03 & 0.68 & \multirow{2}{*}{-} & 1.24 & \multirow{2}{*}{$\begin{array}{c}0.99 \\
(0.42)\end{array}$} & \multirow{2}{*}{-} \\
\hline & & $(-0.64)$ & $(-0.99)$ & $(-0.81)$ & & $(-0.41)$ & & \\
\hline & \multirow{2}{*}{$\Delta \operatorname{lnGDP}_{\mathrm{t}}$} & 0.31 & 0.28 & 0.11 & 0.06 & \multirow{2}{*}{ - } & 0.16 & \multirow{2}{*}{-} \\
\hline & & $(-0.93)$ & $(-0.95)$ & $(-0.99)$ & $(-0.99)$ & & $(-0.98)$ & \\
\hline & \multirow{2}{*}{$\Delta \ln \mathrm{GDP}^{2}{ }_{\mathrm{t}}$} & 0.36 & 0.38 & 0.14 & 0.11 & 0.20 & \multirow{2}{*}{-} & \multirow{2}{*}{-} \\
\hline & & $(-0.87)$ & -0.86 & -0.98 & -0.99 & $(-0.96)$ & & \\
\hline \multirow{12}{*}{ France } & \multirow{2}{*}{$\Delta \ln C_{t}$} & \multirow{2}{*}{-} & 0.00 & 0.01 & 0.02 & 2.07 & \multirow{2}{*}{$\begin{array}{c}1.95 \\
(0.16)\end{array}$} & \multirow{2}{*}{-} \\
\hline & & & -0.96 & $(-0.92)$ & $(-0.89)$ & $(-0.15)$ & & \\
\hline & \multirow{2}{*}{$\Delta \ln N U_{t}$} & 0.10 & - & 1.28 & 0.13 & $2.03 *$ & 1.82 & - \\
\hline & & $(-0.98)$ & - & $(-0.28)$ & $(-0.97)$ & $(-0.09)$ & $(0.13)$ & - \\
\hline & $A \ln D$ & $1.97 *$ & 0.10 & - & $9.31 * * *$ & $2.72 * *$ & $9.29 * * *$ & $-0.02 *$ \\
\hline & $\Delta \operatorname{lnR}_{t}$ & $(-0.1)$ & -0.98 & - & $(0.00)$ & $(-0.03)$ & $(0.00)$ & $(-2.01)$ \\
\hline & & 0.28 & 0.44 & 0.23 & . & $2.77 *$ & 2.51 & - \\
\hline & $\Delta \operatorname{lnEC}_{t}$ & $(-0.75)$ & $(-0.51)$ & $(-0.63)$ & - & $(-0.09)$ & $(0.11)$ & - \\
\hline & & 0.02 & 0.74 & 0.60 & 0.58 & 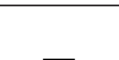 & 0.64 & \\
\hline & $\Delta \operatorname{lnGDP}{ }_{t}$ & $(-1.00)$ & $(-0.56)$ & $(-0.67)$ & $(-0.68)$ & - & $(0.63)$ & - \\
\hline & $1 \ln \mathrm{DP}^{2}$ & 0.01 & 0.07 & 0.01 & 0.52 & $4.11 * *$ & 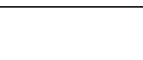 & 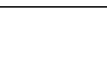 \\
\hline & $\Delta \operatorname{InUDP}_{\mathrm{t}}$ & $(-0.91)$ & $(-0.80)$ & $(-0.90)$ & $(-0.47)$ & $(-0.04)$ & - & - \\
\hline & & - & 0.17 & 1.50 & 0.89 & 1.58 & 1.58 & \\
\hline & $\Delta \ln C_{t}$ & - & $(-0.93)$ & $(-0.20)$ & $(-0.49)$ & $(-0.17)$ & $(-0.17)$ & - \\
\hline & & $6.98^{* * *}$ & & $2.27^{* * *}$ & 3.79 & 8.37 & 8.42 & -0.12 \\
\hline & $\Delta \ln N U_{t}$ & $(0.00)$ & - & $(-0.04)$ & $(0.00)$ & $(0.00)$ & $(0.00)$ & $(-5.59)$ \\
\hline & & 0.40 & 0.48 & 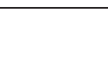 & 0.5 & $2.03^{*}$ & $2.00 *$ & - \\
\hline & $\Delta \operatorname{lnR} E_{t}$ & $(-0.88)$ & $(-0.82)$ & - & $(-0.81)$ & $(-0.07)$ & $(-0.07)$ & - \\
\hline Japan & & 0.28 & 0.93 & 1.60 & & $2.75^{* *}$ & $2.56 * *$ & \\
\hline & $\Delta \operatorname{lnEC} C_{t}$ & $(-0.92)$ & $(-0.47)$ & $(-0.15)$ & - & $(-0.02)$ & $(-0.03)$ & - \\
\hline & & 6.90 & $11.56^{* * *}$ & 0.53 & $10.22^{* * *}$ & - & $4.13^{* * *}$ & $-0.01 *$ \\
\hline & $\Delta \mathrm{InUDP}_{\mathrm{t}}$ & $(0.00)$ & $(0.00)$ & $(-0.75)$ & $(0.00)$ & - & $(0.00)$ & $(-1.96)$ \\
\hline & & $8.05^{* * * *}$ & $10.26^{* * *}$ & 0.59 & $9.68^{* * * *}$ & $3.78^{* * *}$ & & -0.05 \\
\hline & $\Delta \operatorname{lnGDP}_{\mathrm{t}}^{2}$ & $(0.00)$ & $(0.00)$ & $(-0.71)$ & $(0.00)$ & $(0.00)$ & - & $(-0.88)$ \\
\hline
\end{tabular}

itself didn't depend on energy consumption. Similarly, there was a long-run unidirectional causality from economic growth to nuclear power in the U.S., indicating that the development of the economy incentivized the expansion of nuclear power, not the other way around. In the meantime, the growth and success of America's nuclear industry also gave rise to the prosperity of other clean energy industries. This outcome is consistent with the policy direction regarding the development of nuclear power, which currently accounts for about one fifth of the country's electricity.

For France, unidirectional causality is not found from $\mathrm{NC}$ to GDP, yet unidirectional causality relationships are found running from GDP, $\mathrm{CO}_{2}$, and $\mathrm{EC}$ to $\mathrm{RE}$, from GDP to NC, and from GDP to EC. Fifty quarters will be needed for the renewable system to adjust to equilibrium after a short-term shock, indicating that economic and emissions growth are the granger causes of the 
development of renewables in France. This outcome supports France's efforts in lowering the share of nuclear power while increasing the share of renewables in its energy mix. However, great challenges are facing the country as nuclear power currently accounts for $70 \%$ of the energy mix and it is expansion is also caused by economic growth.

According to the results in Table 2, several groups of causal relationships existed in Japan. Bidirectional causalities running from NU to GDP and from EC to GDP were found, and unidirectional causalities running from $\mathrm{CO}_{2}$ to GDP, from $\mathrm{CO}_{2}$ to $\mathrm{NU}$, from RE to NU, from $\mathrm{EC}$ to $\mathrm{NU}$, and from GDP to RE were found in the short run. In the long run, expansion of nuclear and economic significantly impacted the development of nuclear, and it took 8 and 100 quarters for the system to adjust to equilibrium. This result reveals the importance of nuclear power and renewable energy on economic growth in Japan, and also reflects the high dependence of Japan's economic prosperity on energy consumption.

Similar experiences are found in China, the U.S., and France regarding the causal relationships among NC, RE, and GDP. For example, unidirectional causality running from GDP to NU or from GDP to $\mathrm{RE}$ is available for these countries, indicating that the development of nuclear and renewables was the outcome as opposed to the cause of economic growth. Accordingly, the adoption of policies for energy conservation and clean energy development such as carbon pricing, emission standards, and energy efficient regulation would not impede economic prosperity. In so doing, both decoupling energy consumption from economic growth and the extra bonus generated from the greenness and quality improvement of the energy system could be achieved simultaneously.

By contrast, bidirectional causalities between GDP and EC and GDP and NU were found in Japan, supporting the feedback hypothesis for the country. This conclusion reflects the difficulties facing Japan with its nuclear exit policies, as declining nuclear use would harm the country's economic growth greatly. A stable electricity supply is critical for Japan's economy as the country is highly dependent on its manufacturing industries such as the automotive, electronics, iron and steel, and chemical industries [54]. In addition, Japan is an energy-lacking region with $80 \%$ external energy dependence, and nuclear power has been a major component in its energy mix. Repeated attempts by the Japanese government to restart its nuclear power projects has supported the findings in this study.

As can be seen from the empirical results of the four countries, the question of how to improve the benefits of nuclear and renewables to facilitate the green growth of energy in China is one of the biggest challenges facing the Chinese government. Advanced experience and beneficial practices regarding low-carbon development from the U.S., France, and Japan should be carefully researched and referenced while taking into account China's current situation and future outlook.

\section{Conclusions and Policy Implications}

The essence of energy policy-making is about how to boost the transition of energy industries by optimizing energy systems to provide sufficient, stable, and clean energy for an economy. Therefore, decisions regarding energy use should not only focus on de-carbonization but also on their impacts on economic growth. This study has tested the causal relationships of nuclear power generation, renewable electricity generation, carbon emissions, and economic growth. The results confirm the comparative advantages of nuclear and renewables over traditional energy sources in term of emission reduction. Additionally, empirical tests for China, the U.S., and France all support the "conservation hypothesis" and the "neutrality hypothesis". The conclusions indicate that conservation-oriented energy policies won't harm economic prosperity in China, which leaves more room for making policy.

Priorities should be given to the following aspects in China by referencing experiences of the other three countries as well as considering its own situations:

(1) Green energy development strategy should be prompted to facilitate energy transition. Unlike the other countries, fossil fuels represented by coal still dominate China's energy supply. Yet this situation also leaves the country significant space for the increase of renewable energy. Importance of the low-carbon and green transition of energy systems is commonly acknowledged by the international community. For example, the U.S. government has proposed to increase the share of renewables in its energy mix to $27 \%$ and the share of renewables in electricity production to $50 \%$ by 2030 [55]. In China's economic transition, continuous development of green energy represented by renewables is key to the full-greenness of China's energy system.

(2) Mechanisms supporting clean-tech innovations should be set up to de-carbonize the energy industry. In light of the large share of fossil fuels in the current mix as well as the strong path dependence in energy systems, the greening of the energy system won't happen quickly. Accordingly, clean-tech innovation should be advocated throughout the whole life cycle of fossil fuels by implementing green finance and carbon pricing policies to make each step and process cleaner and greener. In addition, low-carbonization of the whole industry chain should be prompted in order to achieve a comprehensive greenness of the energy system.

(3) Energy efficiency should be enhanced to conserve resource consumption and decarbonize the economy at the same time. Compared to the U.S., France, and Japan, China's carbon emission factors of nuclear power and renewables were still large without being able to control the growth of total emissions. Lowenergy efficiency was a major reason for the problem. In 2013, energy intensity of China was 0.39 toe per 
dollar, which was far more than the numbers of the U.S. (0.14 toe/dollar), France (0.09 toe/dollar), and Japan (0.08 toe/dollar) during the same period. Therefore, energy conservation and efficiency policies should be further improved and perfected by referencing the successful experience of the advanced countries, especially Japan.

(4) Sustainability of economy, environment, and society within energy utilization should be paid greater attention in policy orientation and implementation. As substitutions for fossil fuels, nuclear and renewable energies both have advantages and disadvantages. Concerns regarding the safety of nuclear power plants and large-scale renewable power generators are the key obstacle to clean energy application. Strategic choices and layout regarding the energy system will not impact current economic development but will play a key role in sustainable development of the society. Accordingly, assessment of the designs and plans of energy systems should be done comprehensively and scientifically from a life-cycle perspective.

\section{Acknowledgements}

The authors are grateful for the support provided by the National Natural Science Foundation of China (71704010, 71320107006, and 71673022), the Science Foundation of the Ministry of Education of China (17YJC630163), and the Research Base Program Supported by Social Science Research Foundation of Beijing (18JDYJB021). Fundamental Research Funds for the Central Universities (FRF-TP-18-007A2 and FRFBR-18-001B)

\section{Conflict of Interest}

The authors declare no conflict of interest.

\section{Appendix}

\section{ARDL Models}

$$
\begin{aligned}
& \Delta \operatorname{lnC}=\alpha_{0}+\sum_{i=1}^{m} \alpha_{1 i} \Delta \operatorname{lnC}_{t-i}+\sum_{i=1}^{m} \alpha_{2 i} \Delta \operatorname{lnnU}_{t-i}+\sum_{i=1}^{m} \alpha_{3 i} \Delta \operatorname{lnRE} E_{t-i}+\sum_{i=1}^{m} \alpha_{4 i} \Delta \operatorname{lnEC}_{t-i}+\sum_{i=1}^{m} \alpha_{5 i} \Delta \operatorname{lngDP}_{t-i}+ \\
& \sum_{i=1}^{m} \alpha_{6 i} \Delta \operatorname{lnGDP}_{t-i}^{2}+\alpha_{7} \operatorname{lnC}_{t-1}+\alpha_{8} \operatorname{lnNU} U_{t-1}+\alpha_{9} \operatorname{lnRE} t-1+\alpha_{10} \operatorname{lnEC} C_{t-1}+\alpha_{11} \operatorname{lnGDP}_{t-1}+\alpha_{12} \operatorname{lnGDP}_{t-1}^{2}+\mu_{t} \\
& \Delta \operatorname{lnGDP}=\beta_{0}+\sum_{i=1}^{m} \beta_{1 i} \Delta \operatorname{lnGDP}_{t-i}+\sum_{i=1}^{m} \beta_{2 i} \Delta \operatorname{lnC}_{t-i}+\sum_{i=1}^{m} \beta_{3 i} \Delta \operatorname{lnNU} t_{t-i}+\sum_{i=1}^{m} \beta_{4 i} \Delta \operatorname{lnRE} t_{t-i}+\sum_{i=1}^{m} \beta_{5 i} \Delta \operatorname{lnEC}_{t-i}+ \\
& \sum_{i=1}^{m} \beta_{6 i} \Delta \operatorname{lnGDP}^{2}{ }_{t-i}+\beta_{7} \operatorname{lnGDP}_{t-1}+\beta_{8} \operatorname{lnC}_{t-1}+\beta_{9} \operatorname{lnNU}_{t-1}+\beta_{10} \operatorname{lnRE}_{t-1}+\beta_{11} \operatorname{lnEC}_{t-1}+\beta_{12} \operatorname{lnGDP}_{t-1}^{2}+\mu_{t} \\
& \Delta \operatorname{lnGDP}^{2}=\gamma_{0}+\sum_{i=1}^{m} \gamma_{1 i} \Delta \operatorname{lnGDP}_{t-i}^{2}+\sum_{i=1}^{m} \gamma_{2 i} \Delta \operatorname{lnC}_{t-i}+\sum_{i=1}^{m} \gamma_{3 i} \Delta \operatorname{lnNU}_{t-i}+\sum_{i=1}^{m} \gamma_{4 i} \operatorname{lnRE}_{t-i}+\sum_{i=1}^{m} \gamma_{5 i} \Delta \operatorname{lnEC} t-i^{+} \\
& \sum_{i=1}^{m} \gamma_{6 i} \Delta \operatorname{lnGDP}_{t-i}+\gamma_{7} \operatorname{lnGDP}^{2}+\gamma_{8} \operatorname{lnC}_{t-1}+\gamma_{9} \operatorname{lnNU}_{t-1}+\gamma_{10} \operatorname{lnRE}_{t-1}+\gamma_{11} \operatorname{lnEC}_{t-1}+\gamma_{12} \operatorname{lnGDP}_{t-1}+\mu_{t} \\
& \Delta \operatorname{lnEC}=\eta_{0^{+}}+\sum_{i=1}^{m} \eta_{1 i} \Delta \operatorname{lnEC}_{t-i}+\sum_{i=1}^{m} \eta_{2 i} \Delta \operatorname{lnC}_{t-i}+\sum_{i=1}^{m} \eta_{3 i} \Delta \operatorname{lnNU}_{t-i}+\sum_{i=1}^{m} \eta_{4 i} \operatorname{lnRE}_{t-i}+\sum_{i=1}^{m} \eta_{5 i} \Delta \operatorname{lnGDP}_{t-i}+ \\
& \sum_{i=1}^{m} \eta_{6 i} \Delta \operatorname{lnGDP}_{t-i}^{2}+\eta_{7} \operatorname{lnEC}_{t-1}+\eta_{8} \operatorname{lnC}_{t-1}+\eta_{9} \operatorname{lnNU}_{t-1}+\eta_{10} \operatorname{lnRE}_{t-1}+\eta_{11} \operatorname{lnGDP}_{t-1}+\eta_{12} \operatorname{lnGDP}_{t-1}^{2}+\mu_{t} \\
& \Delta \operatorname{lnNU}=\lambda_{0}+\sum_{i=1}^{m} \lambda_{1 i} \Delta \operatorname{lnNU}_{t-i}+\sum_{i=1}^{m} \lambda_{2 i} \Delta \operatorname{lnC}_{t-i}+\sum_{i=1}^{m} \lambda_{3 i} \Delta \operatorname{lnEC}_{t-i}+\sum_{i=1}^{m} \lambda_{4 i} \operatorname{lnRE}_{t-i}+\sum_{i=1}^{m} \lambda_{5 i} \Delta \operatorname{lnGDP}_{t-i}+ \\
& \sum_{i=1}^{m} \lambda_{6 i} \Delta \operatorname{lngDP}_{t-i}^{2}+\lambda_{7} \operatorname{lnNU}_{t-1}+\lambda_{8} \operatorname{lnC}_{t-1}+\lambda_{9} \operatorname{lnRE}_{t-1}+\lambda_{10} \operatorname{lnEC}_{t-1}+\lambda_{11} \operatorname{lnGDP}_{t-1}+\lambda_{12} \operatorname{lnGDP}_{t-1}^{2}+\mu_{t} \\
& \Delta \operatorname{lnRE}=\omega_{0}+\sum_{i=1}^{m} \omega_{1 i} \Delta \operatorname{lnRE} E_{t-i}+\sum_{i=1}^{m} \omega_{2 i} \Delta \operatorname{lnC}_{t-i}+\sum_{i=1}^{m} \omega_{3 i} \Delta \operatorname{lnEC} t_{t-i}+\sum_{i=1}^{m} \omega_{4 i} \Delta \operatorname{lnNU} U_{t-i}+\sum_{i=1}^{m} \omega_{5 i} \Delta \operatorname{lngDP}_{t-i}+ \\
& \sum_{i=1}^{m} \omega_{6 i} \Delta \operatorname{lnGDP}_{t-i}^{2}+\omega_{7} \operatorname{lnRE}_{t-1}+\omega_{8} \operatorname{lnC}_{t-1}+\omega_{9} \operatorname{lnNU}_{t-1}+\omega_{10} \operatorname{lnEC}_{t-1}+\omega_{11} \operatorname{lnGDP}_{t-1}+\omega_{12} \operatorname{lnGDP}_{t-1}+\mu_{t}
\end{aligned}
$$

...where $\alpha 0, \beta 0, \lambda 0, \theta 0, \delta 0$, and $\eta 0$ are intercept terms and $\mu \mathrm{t}$ is white noise. 


\section{References}

1. KAYGUSUZ K. Energy and environmental issues relating to greenhouse gas emissions for sustainable development in Turkey. Renewable \& Sustainable Energy Reviews, 13 (1), 253, 2009.

2. DONG F., LONG R., YU B., et al. How can China allocate $\mathrm{CO}_{2}$ reduction targets at the provincial level considering both equity and efficiency? Evidence from its Copenhagen Accord pledge. Resources, Conservation \& Recycling, 130, 31, 2018.

3. DONG F., LONG R., LI Z., et al. Analysis of carbon emission intensity, urbanization and energy mix: evidence from China. Natural Hazards, 82, 1375, 2016.

4. DONG F., LONG R., BIAN Z., et al. Applying a Ruggiero three-stage super-efficiency DEA model to gauge regional carbon emission efficiency: evidence from China. Natural Hazards, 87 (3), 1, 2017.

5. DONG F., YU B., HADACHIN T., DAI Y., et al. Drivers of carbon emission intensity change in China. Resources, Conservation and Recycling, 129, 187, 2018.

6. WANG X.D. Thailand: Clean Energy for Green LowCarbon Growth, the World Bank Group, Washington, 2011.

7. SCHEIDER M., FROGGATT A., et al. The World Nuclear Industry Status Report 2013, Mycle Schneider Consulting, London, 2013.

8. LI R.J., ZHANG L., ZHAO L.D. China's clean energy use, factor allocation structure and carbon Productivity growth based on production function with energy and human capital, Resource Science, 38, 645, 2016.

9. EEA. Renewable energy in Europe 2016, Publications Office of the European Union, Luxembourg, 2016.

10. KIVYIRO P., ARMINEN H. Carbon dioxide emissions, energy consumption, economic growth, and foreign direct investment: Causality analysis for Sub-Saharan Africa. Energy, 74, 595, 2014.

11. KRAFT J., KRAFT A. Relationship between energy and GNP. Journal of Energy and Development, 3 (2), 401, 1978.

12. AL-IRIANI M.A. Energy - GDP relationship revisited: an example from GCC countries using panel causality. Energy Policy, 34 (17), 3342, 2006.

13. MEHRARA M. Energy consumption and economic growth: the case of oil exporting countries. Energy Policy, 35 (5), 2939, 2007.

14. ALAM M.J., BEGUM I.A., BUYSSE J., et al. Energy consumption, carbon emissions and economic growth nexus in Bangladesh: cointegration and dynamic causality analysis. Energy Policy, 45, 217, 2012.

15. MARQUES A.C., FUINHAS J.A. Is renewable energy effective in promoting growth? Energy Policy, 46, 434, 2012.

16. CHANG T. Causal relationship between nuclear energy consumption and economic growth in G6 countries: Evidence from panel Granger causality test. Progress in Nuclear Energy, 77, 187, 2014.

17. STERN D.I. A multivariate cointegration analysis of the role of energy in the US macroeconomy. Energy Economics, 22, 267, 2000.

18. OH W., LEE K. Causal relationship between energy consumption and GDP: the case of Korea 1970-1999. Energy Economics, 26 (1),51, 2004.

19. YUAN J., KANG J.-G., ZHAO C., et al. Energy consumption and economic growth: evidence from China at both aggregated and disaggregated levels. Energy Economics, 30, 3077, 2008.

20. NARAYAN P.K., SMYTH R. Energy consumption and real GDP in G7 countries: new evidence from panel cointegration with structural breaks. Energy Economics, 30, 2331, 2008.

21. APERGIS N., PAYNE J.E. Energy consumption and economic growth in Central America: evidence from a panel cointegration and error correction model. Energy Economics, 31, 211, 2009.

22. MASIH A.M.M., MASIH R. On temporal causal relationship between energy consumption, real income and prices; some new evidence from Asian energy dependent nics based on a multivariate cointegration/vector error correction approach. Journal of Policy Model, 19, 417, 1997.

23. PAUL S., BHATTACHARYA R.N. Causality between energy consumption and economic growth in India: a note on conflicting results. Energy Economics, 26 (6), 977, 2004.

24. LEE C.C., CHANG C.P., CHEN P.F. Energy-income causality in OECD countries revisited: the key role of capital stock. Energy Economics, 30, 2359, 2008.

25. CHENG B. An investigation of cointegration and causality between energy consumption and economic growth. Journal of Energy Development, 21, 73, 1995.

26. JOBERT T., KARANFIL F. Sectoral energy consumption by source and economic growth in Turkey. Energy Policy, 35, 5447, 2007.

27. OMRI A. An international literature survey on energyeconomic growth nexus: Evidence from country-specific studies. Renewable and Sustainable Energy Reviews, 38 (9), 951, 2014

28. ARMEANU D., GEORGETA V., ŞTEFAN C. Does renewable energy drive sustainable economic growth? Multivariate panel data evidence for EU-28 countries. Energies, 10, 381, 2017.

29. SARI R., EWING B.T., SOYTAS U. The relationship between disaggregate energy consumption and industrial production in the United States: an ARDL approach. Energy Economics, 30, 2302, 2008.

30. SADORSKY P. Renewable energy consumption and income in emerging economies. Energy Policy, 37, 4021, 2009.

31. MENYAH K., WOLDE-RUFAEL Y. $\mathrm{CO}_{2}$ emissions, nuclear energy, renewable energy and economic growth in the US. Energy Policy, 38 (6), 2911, 2010.

32. BOWDEN N., PAYNE J.E. Sectoral analysis of the causal relationship between renewable and non - Renewable energy consumption and real output in the US. Energy Source Part B, 5 (4), 400, 2010.

33. WOLDE-RUFAEL Y. Nuclear energy consumption and economic growth in Taiwan. Energy Sources, Part B: Economics, Planning, and Policy, 7 (1), 21, 2012.

34. YOO S.H., KU S.J. Causal relationship between nuclear energy consumption and economic growth: a multicountry analysis. Energy policy, 37 (5), 1905, 2009.

35. WOLDE-RUFAEL Y. Bounds test approach to cointegration and causality between nuclear energy consumption and economic growth in India. Energy Policy, 38 (1), 52, 2010.

36. MBAREK M.B., KHAIRALLAN R., FEKI R. Causality relationships between renewable energy, nuclear energy and economic growth in France. Environment Systems and Decisions, 35 (1), 133, 2015. 
37. IWATA H., OKADA K., SAMRETH S. Empirical study on the environmental Kuznets curve for $\mathrm{CO}_{2}$ in France: The role of nuclear energy. Energy Policy, 38 (8), 4057, 2010.

38. BAEK J., KIM H.S. Is economic growth good or bad for the environment? Empirical evidence from Korea. Energy Economics, 36, 744, 2013.

39. APERGIS N., PAYNE J.E. A panel study of nuclear energy consumption and economic growth. Energy Economics, 32, 545, 2010.

40. MEZ L. Nuclear and Renewables: Compatible or Contradicting? Wiley Interdisciplinary Reviews: Energy and Environment, 1 (2), 218, 2012.

41. PEARCE J.M. Thermodynamic limitations to nuclear energy deployment as a greenhouse gas mitigation technology. International Journal of Nuclear Governance, Economy and Ecology, 2 (1), 113, 2008

42. KENNY R., LAW C., PEARCE J.M. Towards real energy economics: Energy policy driven by life-cycle carbon emission. Energy Policy, 38 (4), 1969, 2010.

43. MCNEIL B. The costs of introducing nuclear power to Australia. Journal of Australian Political Economy, 6 (59), 5, 2007.

44. FOLLAND S., HOUGH R. Externalities of nuclear power plants: Further evidence. Journal of Regional Science, 40 (4), 735, 2000.

45. REN21. Renewables 2016 Global Status Report, REN21 Secretariat, Paris, 2016.

46. EIA. International Energy Statistics, https://www.eia.gov/ forecasts/ieo/electricity.cfm (accessed on 10 Dec 2017)
47. ENGLE R.F., GRANGER C.W.J. Cointegration and error correction representation: estimation and testing, Econometrica, 55, 251, 1987.

48. JOHANSEN W., KRUGER S.F. Maximum likelihood estimation and inference on cointegration- with applications to the demand for money, Oxford Bulletin of Economics and Statistics, 52, 169, 1990.

49. PESARAN M.H., SHIN Y.,SMITH R.J. Bounds testing approaches to the analysis of level relationships, Journal of Applied Economics, 16, 289, 2001.

50. LUKEPOHL H. Structural vector autoregressive analysis for cointegrated variables, Allgemeines Statistisches Archiv, 90, 75, 2006.

51. NARAYAN P.K. The saving and investment nexus for China: evidence from cointegration tests, Applied Economics, 37, 1979, 2005.

52. SHAHBAZ M. Economic growth, energy consumption, financial development, international trade and $\mathrm{CO}_{2}$ emissions in Indonesia, Journal of Renewable \& Sustainable Energy, 25, 109, 2013.

53. LI S. Research on calculation of new energy's power generation efficiency and analysis on its driving factors, Recourse Science, 38, 321, 2016.

54. WANG X.E., WANG H.N., XIA J., et al. Typical country's coordinated development of the economy- society and energy-environment during industrialization, Resource Science, 38, 2001, 2016.

55. INTERNATIONAL RENEWALBE ENERGY AGENCY. Renewable Energy Prospects: RE map 2030 analysis for United States of America, United Arab Emirates, Abu Dhabi, 2015. 
